\title{
ОЗНАКИ ІНСТИТУТУ СОМАТИЧНИХ ПРАВ ЛЮДИНИ
}

\section{ТУРЯНСЬКИЙ Юрій Іванович - доктор економічних наук, член НКР Конституційного суду України \\ DOI:10.32782/EP.2020.1.1}

\begin{abstract}
У статті виділено ознаки соматичних прав як групи прав нового покоління. Визначено, шо соматичні права слід розуміти як групу прав людини, щзо безпосереднъо пов'язані з тілом людини, та включають: 1) право вирішувати особливості функціонування та зовнішнъого виразу изілісного тіла як людський організм; 2) здійснювати такі дї̈ відповідно до певного органу/органів чи тканин; 3) права людини розпоряджатися тими біологічними компонентами, які вже відмежовані від ї̈ тіла, наприклад частини тканин, ДНК, кров, сперма тощо.
\end{abstract}

Визначається новизна суспільних відносин як ознака інституту соматичних прав, шо спричиняе невизначеність та неоднозначність правового регулювання. Також доведено, що основним атрактором (иинником) появи нової групи $\epsilon$ розвиток науки, тому наступною ознакою $є$ залежність соматичних прав від знань, прогресу та реалізащї здобутків медицини, біологій, генетики та техніки. Спричинені науковим розвитком, соматичні права залежать від наступного прогресу вказаних сбер.

Акцентовано, щзо новизна породжує невизначеність, тому вагомою рисою $\varepsilon$ відсутність єдиних системних міжнародних, загальнолюдсъких підходів, узгоджених юридичних позицій щодо правового регулювання групи изих прав.

Звернуто увагу, що значна моральна, релігійна, етична протидія повної імплементацї можливостей медицини та технологій, що пов'язані з тілом людини та ї органами. Вказана ознака полягає у радикальній протидї моральних норм $i$ нових правових можливостей, які пов'язані з тілом людини. При взаємодї права та моралі норми права визначаються ефективними, при інших умовах наступає суттева моральна протидія.

Вказано, що соматичні права є похідними від особистих прав людини як невідемних, невідсужуваних абсолютних прав. Вони повною мірою не збігаються з ними. Проте право на життя як ключове право людини забезпечує право на здоровя людини $і$ відповідно право розпоряджатися свойм тілом на своє благо. Особисті права як права першого покоління покликані створити автономне середовище для реалізації волі людини, забезпечити ї̈ свободу та юридичну захищеність.

Доведено винятковість правової ситуачій у соматичних правах, що породжує наслідки часто незворотнього характеру та вказано на комплексність реалізачї соматичного права, оскільки воно породжує відносини різних галузей права.

Автором вказано, що соматичні права відображають людиноцентричну правову ідеологію та рівень визнання соматичних прав вказує на сутність держави, може слугувати критерієм визнання ї̈ демократичності, правності, толерантності та відображає рівень розвитку правової культури та держави загалом.

Ключові слова: соматичні права, медицина, права нового покоління, ознаки, тіло людини. 


\section{Теорія, історія держави і права. Конституційне право}

\section{Вступ}

Під впливом новітніх технологій, розвитку наукового прогресу розширюються правові можливості, які формують новітній інститут права - права людини четвертого покоління. Серед них суттєву групу займають соматичні права людини (ще вони можуть носити назву «тілесні»). В сучасну епоху активно вимілюються права, що грунтуються на можливостях та автентичній волі людини самостійно вирішувати питання, що стосуються іiі тіла, тобто здійснювати дії що стосуються його удосконалення, видозміни, реконструкції і навіть анолювання себе як живої людської істоти. До видів прав людини, що відноситься до соматичних прав можна віднести: право на смерть, зміну статі, одностатеві сексуальні контакти, трансплантацію органів, вживання наркотиків або психотропних засобів, право на використання новітніх репродуктивних технологій, стерилізацію, аборт, навіть клонування та відтворення себе у віртуальній реальності. Враховуючи новизну і невизначеність вказаних можливостей, такі права потребують особливого аналізу, та не можуть повною мірою відповідати правовим та морально-етичним засадам людського існування. Тому слід науково визначити допустимість імплементації новітніх можливостей в національне законодавство та прийнятність виокремлення їх в інститут прав людини.

\section{Стан дослідження}

Питання генезису прав людини розглядали науковці як з погляду теорії, так і філософії права, зокрема С. Головатий, I. Жаровська, Ю. Бисага, П. Рабінович, С. Сливка, С. Стеценко, О. Скакун, В. Ковальчук та багато інших. Проте комплексного правового аналізу таких прав до сьогодні подано не було.

\section{Постановка завдання}

Метою цієї статті є аналіз ознак соматичних прав людини 3 метою удосконалення понятійно-категоріального апарату цієї групи прав людини.

\section{Виклад основних положень}

Соматичні права як групу прав людини, що безпосередньо пов'язані з тілом людини, та включають: 1) право вирішувати особливості функціонування та зовнішнього виразу цілісного тіла як людський організм; 2) здійснювати такі дії відповідно до певного органу/органів чи тканин; 3) права людини розпоряджатися тими біологічними компонентами, які вже відмежовані від ії тіла, наприклад частини тканин, ДНК, кров, сперма тощо.

Новітній інститут є ще не повною мірою юридично узгодженим. Існують ряд наукових дискусій щодо його термінопонять, правової природи та особливостей правового регулювання. В межах цієї наукової статті ми спробуємо узгодити основні загальнотеоретичні питання.

Видається, що першочергово необхідно встановити ознаки цього нового інституту.

Слід визначити, що вказаний інститут тільки нещодавно став об'єктом наукового аналізу, тому незначна кількість науковців займаються дослідженням задекларованих понять. Серед науковців тільки С. Нетерова виокремлювала наступні ознаки групи соматичних прав: 1) специфічний характер об'єкта цих прав - тіло людини, що виступає об'єктом права власності і має на сьогоднішній день в більшості випадків грошово-вартісне вираження, а також дії по його трансформації і розпорядженням життям; 2) можливість їх практичного здійснення за допомогою досягнень природних і технічних наук (біології, генетики, медицини, фізики, техніки та ін.); 3) колізійність в підходах і висновках про значимість і цінності таких прав з боку релігії, моралі, науки, права; 4) органічна сутнісна зв'язок з основними правами людини в силу особливої зв'язку 3 особистими (природними) правами і відособленість як самостійна група прав людини [1, с.43].

На нашу думку, слід ширше розкрити вказані ознаки, їх пояснити та розширити. Тому пропонуємо наступну систему ознак.

1. Новизна цієї групи прав, що спричиняє невизначеність та неоднозначність правового регулювання. В суспільстві існує круговорот рушійних факторів, коті у своїй взаємодії та боротьбі протилежносте діючи на суспільну реальність змінюють ії. Проте існують сталі та стабільні суспільні інститу- 
ти, що забезпечують основу існування права та соціуму, серед них права людини в демократичному суспільстві. Однак соціальні та правові реалії змінюються при цьому спричиняють появу нових додаткових елементів системи - нову групу прав людини.

2. Основним атрактором (чинником) появи нової групи є розвиток науки, тому наступною ознакою є залежність соматичних прав від знань, прогресу та реалізації здобутків медицини, біології, генетики та техніки. Спричинені науковим розвитком, соматичні права залежать від наступного прогресу вказаних сфер.

3. Новизна породжує невизначеність, тому вагомою рисою $є$ відсутність єдиних системних міжнародних, загальнолюдських підходів, узгоджених юридичних позицій щодо правового регулювання групи цих прав. Як вірно зазначає М. Козюбра «державі як інституту суспільства відводиться роль не стільки спостерігача, скільки хранителя та гаранта тих відносин, які вже впорядковані самим суспільством за допомогою соціальних регуляторів. Саме тому межа втручання держави у суспільне життя пролягає по умовній лінії норм, які вже врегулювали відносини та залишаються досить стабільними і не загрожують правам інших його членів або суспільству в цілому» [2, с.191]. Однак, що робити якщо суспільство не має сформованого соціального інституту, тоді держава повинна самостійно визначити ті правила поведінки, які відповідають загальній правовій ідеології, принципам права які вони декларують. У випадку новітніх відносин саме активна позиція держави повинна бути домінуючою, оскільки при відсутності державного впливу відбуватиметься прогалини в правовому регулюванні, що призведе до порушення прав та свобод членів суспільства, порушення принципів суспільної моралі тощо.

Щодо імплементації соматичних прав, то єдина позиція відсутня. Певні з них практично одностайно імплементовані нормами права, зокрема штучне запліднення методом in vitro чи посмертна транспланталогія. Проте інші ще очікують позитивного національного, та й міжнародного схвалення чи заборони.
4. Значна моральна, релігійна, етична протидія повної імплементації можливостей медицини та технологій, що пов’язані 3 тілом людини та ії органами. Вказана ознака полягає у радикальній протидії моральних норм і нових правових можливостей, які пов’язані з тілом людини. При взаємодії права та моралі норми права визначаються ефективними, при інших умовах наступає суттєва моральна протидія. «Моральна база робить право ефективним і дієвим. Оскільки мораль існує у свідомості людей, то засноване на ній право сприймається ними легко та не викликає суперечностей. Якщо ж право різко суперечить моральним переконанням суспільства, наслідком стане несприйняття, ігнорування та постійні порушення відповідних норм. I навпаки - морально зрозуміле право буде виконуваним. Засобом його забезпечення будуть не лише державний примус, а й громадська думка та осуд» [3, c.363].

Протидія морального та новітньо-правового призводить до того, що нові права можуть визнавати не тільки за хибну ідеологію, але як визначає О. Аьвова «аномалією права». Авторка вказує, що «виходячи 3 природного та невідчужуваного характеру основних прав людини, з огляду на християнську традицію суспільної моралі встановлюються нині відповідні загально прийняті стандарти та норми. Водно час у світі поширюється тенденція відхилятися від згаданих нормативних та моральних мірил, встанов^юючи так звані «нові права» людини, які беруть свій початок не $з$ природних засад, а $\varepsilon$ відображенням ліберальних цінностей, прояву такої свободи, для якої критерії моральності, істинності та справедливості не $є$ межею. Такі відхилення від правильного і нормального, від міри, від норми, прийнято називати аномалією» [4, с.103].

5. Соматичні права 6 похідними від особистих прав людини як невідємних, невідсужуваних абсолютних прав. Вони повною мірою не збігаються 3 ними. Проте право на життя як ключове право людини забезпечує право на здоровя людини і відповідно право розпоряджатися своїм тілом на своє благо. Особисті права як права першого покоління покликані створити 


\section{Теорія, історія держави і права. Конституційне право}

автономне середовище для реалізації волі людини, забезпечити ії свободу та юридичну захищеність.

6. Винятковість правової ситуації, що породжує наслідки часто незворотнього характеру. Зокрема до проблем зміни статі, кореляції геному людини, генетичних транфомацій слід ставитися виважено. Суспільство та держава повинні бути переконаними, що реалізація соматичного права є крайнім засобом і є постійною волею людини.

7. Комплексність реалізації соматичного права, оскільки воно породжує відносини різних галузей права - медичного, сімейного (наприклад потребу визначення материнства при сурогатному методі репродукції, статусу батьківства при зміні статі особи, батьківства при посмертній репродукції, права жінки на аборт), адміністративного (встановлення офіційного статусу особи), конституційного (проблеми громадянства дітей народжених 3 використанням новітній репродуктивних технологій, забезпечення рівності осіб, які надають перевагу одностатевим сексуальним відносинам, встановлення гендерної рівності тощо), кримінального (здійнення незаконної евтаназії) характеру тощо.

8. Соматичні права відображають людиноцентричну правову ідеологію. Право людини використовувати та розпоряджатися своїм тілом, яке схвалене і визнане державою повною мірою репрезентує фокусування права на людині як первинній цінності. «Філософсько-антропологічний підхід у пізнанні правової особистості дає можливість трактувати правову особистість як фокус, у якому переломлені всі виміри людського буття: божественнодуховний, космічний, природний, психічний, соціальний, культурний тощо. Він допомагає побачити зв язок права та людини, іiі природи, світу іiї людського буття, вивести характеристики права з характеристик людини, виявити гуманістичний вимір у праві, його антропологічний зміст, зрозуміти його як невід'ємне від людини явище, передумову іiі повноцінного розвитку, самовизначення та самоздійснення, як міру розвитку їі людської гідності [5, с.66].
7. Рівень визнання соматичних прав вказує на сутність держави, може слугувати критерієм визнання ії демократичності, правності, толерантності та відображає рівень розвитку правової культури та держави загалом.

Дані ознаки дозволяють говорити про соматичних правах як про самостійну категорії, що має здатність відповідати сучасним інтересам особистості, їі потреб.

\section{Висновок}

Соматичні права людини слід розуміти як новітню групу прав четвертого покоління, які пов'язані з можливістю людини розпоряджатися своїм тілом, органами та іiї похідними. До ознак такої групи прав слід віднести наступні: новизна суспільних відносин, що спричиняє невизначеність та неоднозначність правового регулювання; відсутність єдиних міжнародних підходів до правового регулювання; залежність прав від знань та розвитку медицини, біології, генетики та техніки; морально-релігійна колізійність; походять від особистих прав, але не являються їх складовою; комплексний характер норм при реалізації права; передбачають винятковість соціального казусу; відображають людиноцентричну правову ідеологію; врівень визнання визначає сутність державного і суспільного-культурного розвитку.

\section{Аітература}

1. Нестерова Е.М. К вопросу о юридической природе и сущности личных прав человека. Вестник ТГУ. 2015. Вип. 8 (148). С. $71-77$

2. Загальна теорія права: Підручник / За заг. ред. М.І. Козюбри. К.: Ваіте, 2015. 392 c.

3. Геня Б. О. Право і мораль в системі соціонормативного регулювання. Публічне право. 2013. № 2. С. 362-368.

4. Аьвова О. ᄉ. «Нові права» людини як аномалія права. Правова держава. - 2013. Вип. 24. С. 102-109.

5. Братасюк В. М. Аюдина-особистість як суб'єкт права: методологічні засади дослідження. Юридичний часопис Наиіональної академї̈ внутрішніх справ. 2011. № 1(1). С. 64-70. 


\section{Signs of the somatic human tights institute}

The article highlights the signs of somatic rights as a new generation rights group. It has been determined that somatic rights should be understood as a group of human rights directly related to the human body and they include: 1) the right to address the peculiarities of the functioning and external expression of the whole body as a human organism; 2) perform such actions in accordance with a specific organ/organs or tissues; 3) human's rights to dispose of biological components that are already separated from his $\backslash$ her body, such as tissue, DNA, blood, semen, etc.

The novelty of social relations is defined as a sign of the somatic rights institute, which causes uncertainty and ambiguity of legal regulation. It is also proved that the main attractor (factor) of the emergence of a new group is the development of science, so the next sign is the dependence of somatic rights on knowledge, progress and realization of the achievements of medicine, biology, genetics and technology. Caused by scientific development, somatic rights depend on the subsequent progress of the mentioned fields.

It is emphasized that the novelty creates uncertainty, so the lack of a unified systematic international, human-centered approaches, agreed legal positions on the legal regulation of a group of these rights is a significant sign.

It is noted that there's a significant moral, religious, ethical counteraction to the full implementation of medicine and technology re- lated to the human body and its organs. This sign lies in a radical counteraction of the moral standards and new legal possibilities that are related to the human body. Under the interaction of law and morality, the rules of law are determined effective, in other circumstances, there is a significant moral opposition.

It has been stated that somatic rights are derived from personal human rights as inalienable, unalienable absolute rights. They do not completely coincide with them. However, the right to life as a key human right guarantees the right to human health and, accordingly, the right to dispose of one's body for his/her own good. Personal rights, as the rights of the first generation, are made to create an autonomous environment for the realization of the will of the person, to ensure his/her freedom and legal protection.

The exclusiveness of the legal situation in somatic rights has been proved, which gives rise to the consequences, often of the irreversible nature, and the complexity of the implementation of somatic law is indicated, since it gives rise to relations between different branches of law.

The author states that somatic rights reflect the human-centric legal ideology and the level of recognition of somatic rights indicates the essence of the state, can serve as a criterion for recognition of its democracy, justice, tolerance and reflects the level of development of legal culture and the state as a whole.

Keywords: somatic rights, medicine, new generation rights, signs, human body. 